\title{
PENGARUH MODEL PEMBELAJARAN CIRC BERBANTUAN PENILAIAN PORTOFOLIO TERHADAP KETERAMPILAN MEMBACA PEMAHAMAN
}

\author{
Ni Kadek Sudiarni ${ }^{1}$, Made Sumantri ${ }^{2}$ \\ 1,2 Jurusan PGSD, FIP, Universitas Pendidikan Ganesha \\ Singaraja, Indonesia \\ e-mail: nikadeksudiarni27@yahoo.co.id ${ }^{1}$, made.sumantri@undiksha.co.id ${ }^{2}$, \\ dewanyoman.sudana@undiksha.co.id ${ }^{3}$
}

\begin{abstract}
Abstrak
Penelitian ini bertujuan untuk mengetahui perbedaan yang signifikan keterampilan membaca pemahaman antara kelompok siswa yang dibelajarkan dengan menggunakan model pembelajaran Cooperative Integrated Reading and Composition (CIRC) berbantuan penilaian portopolio dan kelompok siswa yang dibelajarkan tidak menggunakan model pembelajaran Cooperative Integrated Reading and Composition (CIRC) berbantuan penilaian portopolio pada siswa kelas V di Gugus XV Kecamatan Buleleng Tahun Pelajaran 2017/2018. Penelitian ini termasuk eksperimen semu. Desain penelitian ini yaitu non-equivalent post-test only control group design. Populasi penelitian ini yaitu seluruh siswa kelas V di SD Gugus XV Kecamatan Buleleng berjumlah 203 siswa. Sampel penelitian yaitu siswa kelas V SDN 2 Kalibukbuk yang berjumlah 34 orang sebagai kelas eksperimen dan siswa kelas V SDN 2 Anturan yang berjumlah 33 orang sebagai kelas kontrol. Metode pengumpulan data dilakukan dengan metode tes yaitu dengan instrumen tes objektif (pilihan ganda). Data yang diperoleh dianalisis dengan menggunakan teknik analisis statistik deskriptif dan teknik analisis statistik inferensial uji-t. Hasil analisis menunjukkan rata-rata skor keterampilan membaca pemahaman siswa yang menggunakan model pembelajaran CIRC berbantuan penilaian portofolio sebesar 23,47 dan siswa yang dibelajarkan tidak menggunakan model pembelajaran CIRC berbantuan portofolio sebesar 16,09. Pengujian hipotesis menggunakan uji-t menunjukkan bahwa $t_{\text {hitung }}>t_{\text {tabel }}\left(t_{\text {hitung }}=7,73>t_{\text {tabel }}\right.$ $=1,99714)$. Berdasarkan hasil penelitian dapat disimpulkan bahwa terdapat perbedaan yang signifikan keterampilan membaca pemahaman antara siswa yang dibelajarkan dengan menggunakan model pembelajaran (CIRC) berbantuan penilaian portofolio dan siswa yang dibelajarkan tidak menggunakan model pembelajaran Cooperative Integrated Reading and Composition (CIRC) berbantuan penilaian portopolio pada kelas V di SD Gugus XV Kecamatan Buleleng Tahun Pelajaran 2017/2018.
\end{abstract}

Kata kunci: keterampilan membaca pemahaman, CIRC, penilaian portofolio.

\begin{abstract}
This study aimed at discovening the effect of Cooperative Integrated Reading and Composition $(\mathrm{CIRC})$ technique with portfolio assessment towords students' reading comprehension on fifth graders of Buleleng district primary schools cluster XV academic year 2017/2018. This was a quasiexperimental research utilizing non-equivalent post-test only control group design. The population of this study was fifth graders of Buleleng district primary schools cluster XV and they are 203 students. Samples of this study was fifth graders of SDN 2 Kalibukbuk they are 34 students as experimental group, and fifth graders of SDN 2 Anturan they are 33 students as control group. The data collection was using instrument in the from of objective test. Then, the data was analysed using both descriptive and inferential t-test statistical analysis. The result showed that, mean score for experimental group was 23,47 while the mean score for control group was 16,09. Moreover, hypothesis testing revealed that tobs $>\operatorname{tcv}$ (tobs $=7,37>\operatorname{tcv}=1,99714$ ). Based on the result of this study, it can be concluded that there was a significant difference on the students' score of reading comprehension between students taught using Cooperative Integrated Reading and Composition (CIRC) technique with portfolio assessment and those who did not teach with Cooperative Integrated Reading and Composition (CIRC) technique with portfolio assessment on fifth graders og Buleleng district primary schools cluster XV academic year 2017/2018.
\end{abstract}

Keywords: reading comprehension, CIRC, portfolio assessment 


\section{Pendahuluan}

Bahasa Indonesia merupakan bagian dari mata pelajaran di sekolah dasar yang memiliki posisi yang sangat penting karena bahasa Indonesia dijadikan sebagai bahasa negara dan menjadi salah satu identitas bangsa Indonesia. Pembelajaran bahasa Indonesia di Sekolah Dasar memegang peranan penting dalam meningkatkan kemampuan berbahasa siswa. Pada hakikatnya pembelajaran bahasa Indonesia bertujuan untuk meningkatkan kemampuan siswa untuk berkomunikasi secara lisan dan tertulis. pembelajaran bahasa Indonesia memiliki peranan yang sangat penting dalam membentuk kebiasaan, sikap, serta kemampuan siswa untuk tahap perkembangan selanjutnya. Pada pembelajaran bahasa Indonesia mencakup 4 aspek yaitu menyimak, berbicara, membaca, dan menulis. Sudiana (2007:2) menyatakan bahwa, "tidak meragukan bahwa membaca merupakan kunci keberhasilan seorang siswa. Dengan kunci tersebut seorang siswa akan mampu mendalami berbagai ilmu dan mengambil manfaatnya sebagai usaha mengoptimalkan tujuan pembelajaran yang sesungguhnya. Untuk mencapai semua itu, pembelajaran membaca harus dilaksanakan secara terpadu". Kegiatan membaca perlu dibiasakan sejak dini, yakni mulai dari anak mengenal huruf. Jadikan kegiatan membaca sebagai suatu kebutuhan dan menjadi hal yang menyenangkan bagi siswa, sebab seluruh aktivitas sehari-hari selalu melibatkan kemampuan membaca. Membaca dapat dilakukan dimana saja dan kapan saja asalkan ada keinginan, semangat, dan motivasi untuk membaca. Dalam kegiatan membaca terdapat berbagai jenis keterampilan membaca yaitu membaca nyaring, membaca dalam hati, membaca telaah isi, membaca telaah bahasa, membaca pemahaman dan lainnya.

Kenyataan yang saat ini terjadi di lapangan nampaknya tidak seperti yang diharapkan, masih kurangnya kemauan membaca dan kurangnya keterampilan membaca pemahaman di sekolah. Tarigan (1985:56) menyatakan bahwa, membaca pemahaman adalah sejenis membaca yang bertujuan untuk memahami standar-standar, drama tulis, dan pola-pola fiksi. Berdasarkan hal tersebut dapat dilihat membaca pemahaman merupakan suatu kegiatan yang bertujuan untuk mendapatkan informasi yang mendalam serta pemahaman mengenai isi bacaan. Dalam hal ini keterampilan membaca pemahaman sangat penting bagi siswa untuk mempercepat siswa dalam memahami suatu materi.

Berdasarkan hasil observasi dan wawancara ada beberapa faktor yang menyebabkan rendahnya nilai keterampilan membaca siswa yaitu (1) metode yang digunakan guru dalam pembelajaran bahasa Indonesia, khususnya untuk pembelajaran membaca kurang bervariasi, (2) kurangnya interaksi antara siswa dengan siswa dan siswa dengan guru, (3) kurangnya penggunaan penilaian non tes diakhir pembelajaran untuk mengetahui tingkat pemahaman siswa dalam mengikuti pembelajaran khususnya membaca pemahaman. Jika dilihat dari pencatatan dokumen nilai rata-rata siswa dalam keterampilan membaca pada mata pelajaran bahasa Indonesia kelas V di Gugus XV Kecamatan Buleleng masih rendah dan banyak siswa yang mendapatkan nilai dibawah KKM. Sehingga dalam hal ini keterampilan membaca pemahaman siswa sangat berpengaruh terhadap nilai siswa pada mata pelajaran bahasa Indonesia.

Tabel 1. Rata-rata Nilai Keterampilan Membaca Siswa SD Kelas V di Gugus XV Kecamatan Buleleng

\begin{tabular}{cccccccc}
\hline No. & Nama Sekolah & KKM & $\begin{array}{c}\text { Banyak } \\
\text { Siswa }\end{array}$ & \multicolumn{2}{c}{$\begin{array}{c}\text { Siswa mencapai } \\
\text { KKM }\end{array}$} & \multicolumn{2}{c}{$\begin{array}{c}\text { Siswa yang Belum } \\
\text { Mencapai KKM } \\
\%\end{array}$} \\
\hline 1 & SDN 1 Anturan & 70 & 23 & 18 & 78,26 & 5 & 21,74 \\
2 & SDN 2 Anturan & 70 & 33 & 24 & 72,73 & 9 & 27,27 \\
3 & SDN 3 Anturan & 70 & 29 & 18 & 62,07 & 11 & 37,93 \\
4 & Tri Amerta & 75 & 21 & 7 & 33,33 & 14 & 66,67 \\
5 & SDN 2 Kalibukbuk & 75 & 34 & 11 & 32,35 & 23 & 67,65 \\
\hline
\end{tabular}




\begin{tabular}{|c|c|c|c|c|c|c|c|}
\hline \multirow[t]{2}{*}{ No. } & \multirow[t]{2}{*}{ Nama Sekolah } & \multirow[t]{2}{*}{ KKM } & \multirow[t]{2}{*}{$\begin{array}{l}\text { Banyak } \\
\text { Siswa }\end{array}$} & \multicolumn{2}{|c|}{$\begin{array}{c}\text { Siswa mencapai } \\
\text { KKM }\end{array}$} & \multicolumn{2}{|c|}{$\begin{array}{l}\text { Siswa yang Belum } \\
\text { Mencapai KKM }\end{array}$} \\
\hline & & & & Siswa & $\%$ & Siswa & $\%$ \\
\hline 6 & SDN 3 Kalibukbuk & 65 & 24 & 22 & 91,67 & 2 & 8,33 \\
\hline 7 & $\begin{array}{l}\text { SDN } 4 \text { Kalibukbuk } \\
\text { Jumlah }\end{array}$ & 68 & $\begin{array}{c}39 \\
203\end{array}$ & $\begin{array}{c}32 \\
132\end{array}$ & 82,05 & $\begin{array}{c}7 \\
71\end{array}$ & 17,95 \\
\hline & Rata-rata & & & & $65,02 \%$ & & $34,98 \%$ \\
\hline
\end{tabular}

Berdasarkan Tabel 1, dapat diketahui bahwa rata-rata keterampilan membaca di SD Gugus XV Kecamatan Buleleng masih banyak yang belum mencapai KKM. Masih banyak sekolah yang belum mencapai $75 \%$ siswa yang memenuhi KKM. Beberapa sekolah yang banyak siswanya belum mencapai KKM meliputi SDN 2 Kalibukbuk dan Tri Amerta. Sedangkan di SDN 1 Anturan, SDN 2 Anturan, SDN 3 Anturan, SDN 4 Kalibukbuk banyak siswa yang sudah mencapai KKM dikarenakan batas nilai $\mathrm{KKm}$ lebih kecil dibandingkan di SDN 2 Kalibukbuk dan Tri Amerta. Terdapat perbedaan antara siswa yang sudah memenuhi KKM dan yang belum memenuhi KKM. Sehingga dapat dilihat pembelajaran belum optimal.

Untuk mengatasi persoalan tersebut guru hendaknya mampu memperhatikan dan mencermati keadaan yang ada agar proses pembelajaran di kelas lebih efektif. Salah satu yang dapat dilakukan guru yaitu dengan memilih model pembelajaran yang sesuai dengan materi yang akan disampaikan dan menyesuaikan dengan keadaan siswa yang memiliki kemampuan yang berbeda. Salah satu model pembelajaran yang dapat diterapkan untuk mengatasi masalah tersebut adalah model pembelajaran kooperatif. Suantini (2013) menyatakan, "pembelajaran kooperatif (cooperative learning) adalah belajar secara bersama-sama, saling membantu antara satu dengan yang lainnya dalam belajar, dan memastikan bahwa setiap siswa dalam kelompok mencapai tujuan atau tugas yang telah ditentukan sebelumnya". Model pembelajaran kooperatif yang dimaksud adalah model pembelajaran Cooperative Integrated Reading and Composition (CIRC). Shoimin (2014:51) menyatakan, "Cooperative Integrated Reading and Composition (CIRC) merupakan model pembelajaran khusus mata pelajaran bahasa dalam rangka membaca dan menemukan ide pokok, pokok pikiran, atau tema sebuah wacana". Model pembelajaran Cooperative Integrated Reading and Composition (CIRC) dimana siswa dalam membaca sebuah bacaan atau cerita secara bersungguh-sungguh dan dapat memahami serta menceritakan kembali isi bacaan. Model ini terdiri dari tiga tahapan yang meliputi: tahapan prabaca yang mencakup kelompok membaca dan memperkenalkan bacaan atau cerita yang anak baca, tahap membaca yang mencakup membaca dengan pemahaman, menulis isi bacaan, dan tahap pascabaca mencakup menceritakan kembali isi bacaan.

Menurut hasil penelitian yang dilakukan Wedayanti (2013) menyatakan bahwa penerapan model pembelajaran Cooperative Integrated Reading and Composition (CIRC) berbantuan media visual dapat meningkatkan hasil belajar bahasa Indonesia siswa. Hal ini sejalan dengan hasil penelitian yang dilakukan oleh Prabawati (2013) yang menyatakan bahwa Model pembelajaran Cooperative Integrated Reading and Composition (CIRC) Berbantuan Media Gambar Berseri dapat diunggulkan dalam rangka meningkatkan kemampuan membaca pemahaman siswa. Hasil yang sama juga ditunjukkan dari hasil penelitian Kartika (2013) yang menyatakan bahwa model pembelajaran CIRC berbasis Jolly Phonics akan mampu meningkatkan kemampuan membaca dan menulis siswa dibandingkan pembelajaran dengan menggunakan model konvensional. Hal ini dikarenakan kedua model pembelajaran memiliki teori, karakteristik, langkah-langkah pembelajaran dan situasi pembelajaran yang berbeda. Model pembelajaran konvensional didasarkan atas teori belajar behavioristik, dimana pembelajarannya hanya berorientasi pada hasil. Kegiatan pembelajarannya berpusat pada guru (teacher centered) yang menyebabkan situasi pembelajaran menjadi pasif. Lain halnya dalam pembelajaran dengan menggunakan model pembelajaran CIRC berbasis Jolly Phonic. 
Selain penggunaan model pembelajaran yang inovatif, penggunaan penilaian yang tepat mampu mencapai keterampilan membaca siswa. Untuk menilai suatu keterampilan digunakan penilaian non tes. Salah satu penilaian non tes yang cocok digunakan adalah penilaian portofolio. Amirono dan Daryanto (2016:127) menyatakan, "penilaian portofolio merupakan sebagian kumpulan karya atau dokumentasi peserta didik yang tersusun secara sistematis dan terorganisasi yang diambil selama proses pembelajaran, digunakan oleh guru dan peserta didik untuk menilai dan memantau perkembangan, pengetahuan, keterampilan dan sikap peserta didik dalam mata pelajaran tertentu". Pada penilaian portofolio bukti fisik yang berupa benda yang sudah dinilai dalam penilaian produk atau proyek juga dapat diartikan portofolio karena termasuk bukti fisik hasil prestasi siswa. Namun yang perlu diingat, karena hasil produk dan penilaian proyek secara terpisah maka penilaian portofolio ini dibatasi pada bukti fisik yang berupa barang cetakan atau tulisan di atas kertas saja, atau benda-benda lain yang dapat ditulis. Dengan demikian, portofolio dapat berbentuk kertas ulangan harian, kertas ulangan semester, buku pekerjaan rumah, buku pekerjaan sekolah, dan bentu-bentuk lain yang memuat coretan sebagai bukti kinerja siswa. Portofolio yang dikerjakan siswa secara individual dapat disatukan dalam sebuah map berwarna sesuai dengan materi yang didapatkan. Guru dalam hal ini perlu memberikan penjelasan kepada siswa bahwa portofolio yang disimpan dengan baik akan bermanfaat bukan hanya untuk dinilai oleh guru, tetapi bermanfaat bagi siswa sendiri. Dengan mencermati portofolio ini siswa dapat mengetahui bagaimana perkembangan dan kenaikan kinerja mereka sendiri.

Adapun langkah-langkah teknis pembelajaran Cooperative Integrated Reading and Composition (CIRC), Kurniasih dan Sani (2015:92) menyatakan, (1) guru menjelaskan tujuan pembelajaran, dan kemudian membentuk kelompok yang anggotanya kurang lebih 46 orang siswa secara heterogen; (2) guru memberikan meteri berupa kliping atau membacakan tertentu sesuai dengan topik pembelajaran; (3) siswa bekerjasama saling membacakan dan menemukan ide pokok dan memberi tanggapan wacana atau kliping dan tulisan pada lembar kertas; (4) setelah itu siswa mempersentasikan atau membacakan hasil kerja kelompok masing-masing; (5) setelah semua kelompok mendapatkan giliran, maka guru bersama siswa membuat simpulan dari materi yang telah didiskusikan; (6) dan setelah itu guru menutup pelajaran seperti biasanya.

Selain memiliki sintaks yang jelas, model pembelajaran Cooperative Integrated Reading and Composition (CIRC) juga memiliki beberapa kelebihan. Shoimin (2014:54) menyatakan, kelebihan model Cooperative Integrated Reading and Composition (CIRC) adalah: (1) CIRC sangat tepat untuk meningkatkan keterampilan siswa dalam menyelesaikan soal pemecahan masalah; (2) dominasi guru dalam pembelajaran berkurang; (3) siswa termotivasi pada hasil secara teliti karena bekerja dalam kelompok; (4) pada siswa dapat memahami makna soal dan saling mengecek pekerjaan; (5) membantu siswa yang lemah; (6) dapat menyelesaikan soal yang berbentuk pemecahan masalah. Selain itu, model pembelajaran Cooperative Integrated Reading and Composition (CIRC) dapat memberikan sebuah pengalaman bagi siswa, mengasah dan berpikir siswa, memperluas wawasan siswa karena setelah siswa membaca diajarkan siswa untuk dapat menuliskan apa yang telah dipahami dari bacaan tersebut, serta dapat menciptakan suasana pembelajaran yang menarik.

Berdasarkan uraian di atas, maka tujuan dari penelitian ini ialah untuk mengetahui perbedaan yang signifikan keterampilan membaca pemahaman antara kelompok siswa yang dibelajarkan dengan menggunakan model pembelajaran Cooperative Integrated Reading and Composition (CIRC) berbantuan penilaian portofolio dengan kelompok siswa yang dibelajarkan tidak menggunakan model pembelajaran Cooperative Integrated Reading and Composition (CIRC) berbantuan penilaian portofolio pada siswa kelas V di SD Gugus XV Kecamatan Buleleng tahun pelajaran 2017/2018. 


\section{Metode}

Penelitian ini dilaksanakan di SD Gugus XV Kecamatan Buleleng tahun pelajaran 2017/2018. Penelitian ini merupakan penelitian eksperimen dengan jenis penelitian eksperimen semu (quasi experiment). Desain penelitian kuasi eksperimen ini bertujuan untuk menguji pengaruh suatu model pembelajaran dengan cara menerapkan treatment pada kelas eksperimen dan membandingkan hasilnya dengan kelas kontrol. Rancangan penelitian ini menggunakan rancangan non-equivalen post-test only control group design dengan pola sebagai berikut.

Tabel 2. Desain Penelitian

\begin{tabular}{lll}
\hline Kelas & Perlakuan & Post-test \\
\hline $\mathrm{E}$ & $\mathrm{X}$ & $\mathrm{O}_{1}$ \\
$\mathrm{~K}$ & - & $\mathrm{O}_{2}$ \\
\hline
\end{tabular}

(Sumber: (diadaptasi dari Agung, 2014)

Keterangan:

$\mathrm{E}=$ kelompok eksperimen

$\mathrm{K}=$ kelompok kontrol

$\mathrm{X}_{1}=$ Perlakuan berupa penerapan model pembelajaran Cooperative Integated Reading and Composition $(\mathrm{CIRC})$ berbantuan penilaian portofolio.

- $\quad=$ Tidak diberikan perlakuan model pembelajaran Cooperative Integated Reading and Composition (CIRC) berbantuan penilaian portofolio.

$\mathrm{O}_{1}=$ post-test terhadapa kelompok eksperimen

$\mathrm{O}_{2}=$ Post-test terhadap kelompok kontrol.

Populasi dalam penelitian ini adalah seluruh kelas V di SD Gugus XV Kecamatan Buleleng yang berjumlah 203 siswa. Sebelum menentukan kelas sampel terlebih dahulu dilakukan uji kesetaraan terhadap populasi penelitian. Berdasarkan hasil uji kesetaraan menggunakan ANAVA A, diperoleh seluruh populasi setara atau nilai keterampilan membaca siswa di SD Gugus XV Kecamatan Buleleng relatif sama. Selanjutnya, pengambilan sampel dilakukan dengan teknik simple random sampling, yaitu dengan sistem undian. Setelah dilakukannya pengundian terhadap sampel dalam populasi tersebut, yang menjadi sampel penelitian ini adalah siswa kelas V SDN 2 Kalibukbuk dan SDN 2 Anturan yang berjumlah 67 siswa. Kelas sampel yang telah didapatkan kemudian diundi lagi untuk menentukan kelompok eksperimen dan kelompok kontrol. Hasil pengundian diperoleh kelas V SDN 2 Kalibukbuk sebagai kelompok eksperimen dan kelas V SDN 2 Anturan sebagai kelompok kontrol. Kelompok eksperimen akan diberikan perlakuan dengan menggunakan model pembelajaran Cooperative Integrated Reading and Composition (CIRC) berbantuan penilaian portofolio sedangkan kelompok kontrol tidak diberikan perlakuan model pembelajaran Cooperative Integrated Reading and Composition (CIRC) berbantuan penilaian portofolio.

Metode pengumpulan data dalam penelitian ini menggunakan metode tes untuk mengukur ranah kognitif siswa. Metode tes yang digunakan yaitu tes objektif. Tes objektif digunakan diakhir penelitian. Jumlah tes objektif sebanyak 30 soal dengan mengikuti jenjang Taksonomi Bloom yang meliputi ranah kognitif aspek mengingat (C1), memahami (C2) menerapkan (C3), menganalisis (C4), dan mengevaluasi (C5). Teknik analisis data 
yang digunakan adalah teknik analisis deskriptif digunakan untuk mencari skor ratarata/mean, median, modus, standar deviasi (SD), dan varians terhadap masing-masing kelompok. Mean, median, modus data sikap ilmiah siswa kemudian disajikan ke dalam poligon. Penentuan tinggi rendahnya variabel-variabel penelitian dapat ditentukan dari skor rata-rata tiap-tiap variabel dikonvensikan ke dalam PAP skala Lima. Teknik analisis statistik inferensial yang digunakan adalah uji-t independent dengan rumus polled varins untuk menguji hipotesis. Sebelum melakukan uji hipotesis terlebih dahulu dilakukan analisis uji prasyarat yang meliputi uji normalitas dan uji homogenitas.

\section{Hasil dan Pembahasan}

Data hasil penelitian ini yaitu data tentang keterampilan membaca pemahaman siswa yang diperoleh melalui post-tets.

Deskripsi data keterampilan membaca pemahaman memaparkan nilai rata-rata, median, modus, standar deviasi, dan varians. Deksripsi data keterampilan membaca pemahaman disajikan pada Tabel 3.

Tabel 3. Deskripsi Data Keterampilan Membaca Pemahaman

\begin{tabular}{lll}
\hline Hasil Analisis & Kelompok Eksperimen & Kelompok Kontrol \\
\hline Mean & 23,47 & 16,09 \\
Median & 24 & 15,45 \\
Modus & 26,16 & 13,69 \\
Varians & 16,56 & 17,44 \\
Standar Deviasi & 4,07 & 4,18
\end{tabular}

Mean, median, modus keterampilan membaca pemahaman selanjutnya disajikan kedalam kurva poligon. Tujuan dalam penyajian data ini yaitu untuk menafsirkan sabaran data keterampilan membaca pemahaman siswa. Hubungan antara mean (M), median (Me), dan modus (Mo) untuk menentukan kemiringan kurva poligon distribusi frekuensi.

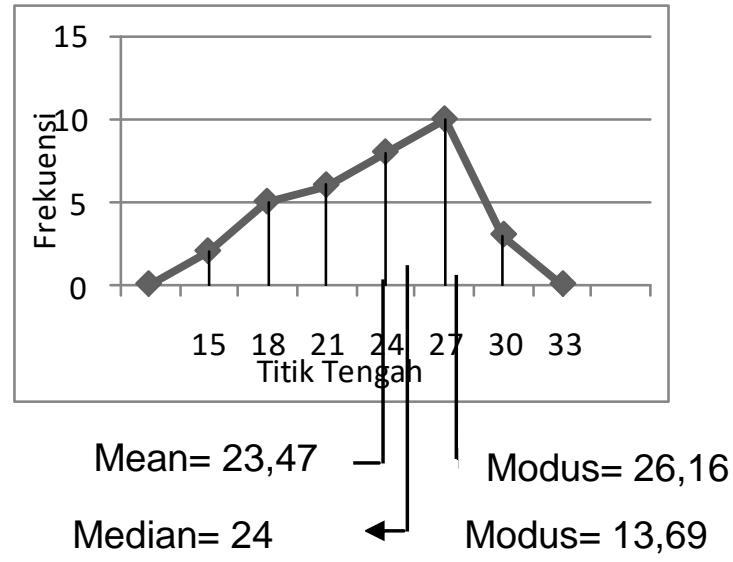

Gambar 1. Grafik Poligon Data Keterampilan membaca Pemahaman Kelompok Eksperimen

Skor mean (M), median (Me), modus (Mo) digambarkan pada grafik polygon tampak bahwa kurva sebaran data kelompok eksperimen menunjukkan juling negatif karena $\mathrm{M}>\mathrm{Md}>\mathrm{Mo}$ (26,16>24>23,47). Hal ini menunjukkan bahwa bagian besar skor keterampilan membaca pemahaman cenderung tinggi. Jika dikonvensikan ke dalam PAP skala Lima 
keterampilan membaca pemahaman siswa kelompok eksperimen berada pada kategori sangat baik.

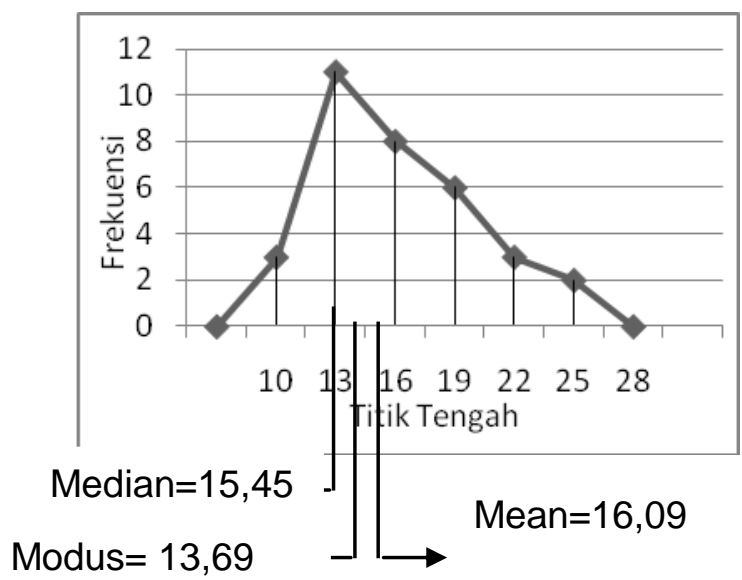

Gambar 2. Grafik Poligon Data Keterampilan Membaca Pemahaman Kelompok Kontrol

Skor mean (M), median (Md), modus (Mo) digambarkan pada grafik poligon tampak bahwa kurva sebaran data kelompok kontrol menunjukkan juling positif karena $M>M d>M o$ $(16,09>15,45>13,69)$. Hal ini menunjukkan bahwa bagian besar skor keterampilan membaca pemahaman cenderung rendah. Jika dikonvensikan ke dalam PAP skala Lima keterampilan membaca pemahaman siswa kelompok kontrol berada pada kategori cukup.

Dari data tersebut menunjukkan bahwa kelompok ekspeimen yang dibelajarkan dengan menggunakan model pembelajaran Cooperative Integrated Reading and Composition $(C I R C)$ berbantuan penilaian portofolio memiliki nilai rata-rata lebih tinggi dibandingkan kelompok kontrol yang dibelajarkan tidak menggunakan model pembelajaran Cooperative Integrated Reading and Composition (CIRC) berbantuan penilaian portofolio. Sebelum dilanjutkan pada pengujian hipotesis, terlebih dahulu dilakukan pengujian asumsi terhadap data yang diperoleh meliputi uji normalitas sebaran data dan uji homogenitas varians. Berdasarkan perhitungan data keterampilan membaca pemahaman dengan menggunakan rumus chi-kuadrat, diperoleh $x_{\text {hit }}^{2}$ hasil post-test kelompok eksperimen adalah 3,0524 dan $x_{\text {tab }}^{2}$ dengan taraf signifikan $5 \%$ dan $\mathrm{db}=3$ adalah 7,815 . Hal ini menunjukkan $x_{\text {hit }}^{2}$ hasil posttest kelompok eksperimen lebih kecil dari $x_{\text {tab }}^{2}\left(x^{2}{ }_{\text {hit }}<x_{\text {tab }}^{2}\right)$, sehingga data hasil post-test kelompok eksperimen berdistribusi normal.

Hasil perhitungan data keterampilan membaca pemahaman dengan menggunakan rumus chi-kuadrat, diperoleh $x_{\text {hit }}^{2}$ hasil post-test kelompok kontrol adalah 3,4602 dan $x_{\text {tab }}^{2}$ dengan taraf signifikan $5 \%$ dan $\mathrm{db}=3$ adalah 7,815 . Hal ini berarti, $x_{\text {hit }}^{2}$ hasil post-test kelompok kontrol lebih kecil dari pada $x_{\text {tab }}^{2}\left(x^{2}{ }_{h i t}<x_{\text {tab }}^{2}\right)$, sehingga data hasil post-test kelompok kontrol berdistribusi normal.

Uji homogenitas varians antar kelompok eksperimen dan kelompok kontrol menggunakan uji Fisher . berdasarkan perhitungan dari uji homogenitas didapatkan $F_{\text {hitung }}=$ 1,053. Sedangkan nilai $F_{\text {tabel }}$ pada $\mathrm{db}_{\text {pembilang }}=32, \mathrm{db}_{\text {penyebut }}=33$ dan taraf signifikan $5 \%$ adalah 1,7934. Hal ini berarti $F_{\text {hitung }}=1,053<F_{\text {tabel }} 1,7934$, sehingga keterampilan membaca pemahaman siswa pada kelompok eksperimen dan kelompok kontrol homogen.

Pengujian hipotesis menggunakan uji-t dengan rumus polled varians. Diketahui bahwa $\bar{X}_{1}$ $=23,47 ; \bar{X}_{2}=16,09 ; S_{1}^{2}=16,56 ; \quad S_{2}^{2}=17,44 ; \mathrm{n}_{1}=34 ;$ dan $\mathrm{n}_{2}=33$. Hasil perhitungan uji-t disajikan pada tabel 4 . 
Tabel 4. Hasil Perhitungan Uji-t

\begin{tabular}{lllllll}
\hline Data & Kelompok & $\mathrm{N}$ & $\bar{X}$ & $\mathrm{~s}^{2}$ & $\mathrm{t}_{\text {hitung }}$ & $\mathrm{t}_{\text {tabel }}(\mathrm{t} . \mathrm{s.5 \%})$ \\
\hline Keterampilan & Eksperimen & 34 & 23,47 & 16,56 & \multirow{2}{*}{1,37} & \multirow{2}{*}{1,99714} \\
Membaca & Kontrol & 33 & 16,09 & 17,44 & 7,37 & \\
Pemahaman & & & & &
\end{tabular}

Berdasarkan Tabel 4, diketahui bahwa nilai $t_{\text {hitung }}$ lebih besar dari nilai $t_{\text {tabel }}$ yaitu $(7,73$ $>$ 1,99714) sehingga $\mathbf{H}_{0}$ ditolak dan $\mathbf{H}_{\mathbf{l}}$ diterima. Hasil uji hipotesis tersebut, dapat diinterprestasi terdapat perbedaan yang signifikan keterampilan membaca pemahaman antara kelompok siswa yang dibelajarkan dengan menggunakan model pembelajaran Cooperative Integrated Reading and Composition (CIRC) berbantuan penilaian portofolio dibandingkan dengan kelompok siswa yang dibelajarkan tidak menggunakan model pembelajaran Cooperative Integrated Reading and Composition (CIRC) berbantuan penilaian portofolio. Adanya perbedaan yang signifikan menunjukkan penggunaan model pembelajaran Cooperative Integrated Reading and Composition (CIRC) berbantuan penilaian portofolio berpengaruh positif terhadap keterampilan membaca pemahaman siswa kelas V di SD Gugus XV kecamatan Buleleng tahun Pelajaran 2017/2018.

Hasil analisis data keterampilan membaca pemahaman menunjukkan bahwa terdapat perbedaan yang signifikan model pembelajaran Cooperative Integrated Reading and Composition (CIRC) berbantuan penilaian portofolio terhadap keterampilan membaca pemahaman pada siswa kelas V di SD Gugus XV Kecamatan Buleleng. Tinjauan ini didasari pada rata-rata skor keterampilan membaca pemahaman siswa dan hasil uji-t. Rata-rata skor keterampilan membaca pemahaman yang mengikuti pembelajaran dengan menggunakan model pembelajaran Cooperative Integrated Reading and Composition (CIRC) berbantuan penilaian portofolio adalah 23,47 termasuk kategori sangat baik dan rata-rata skor keterampilan membaca pemahaman siswa yang dibelajarkan tidak menggunakan model pembelajaran Cooperative Integrated Reading and Composition (CIRC) berbantuan penilaian portofolio adalah 16.09 termasuk kategori cukup. Hal ini menunjukkan bahwa keterampilan membaca pemahaman siswa kelompok eksperimen lebih tinggi dibandingkan siswa kelompok kontrol.

Selanjutnya berdasarkan analisis data menggunakan uji-t, diketahui $t_{\text {hitung }}=7,37$ dan $t_{\text {tabel }}$ pada taraf signifikan $5 \%=1,99714$. Hasil perhitungan tersebut menunjukkan bahwa $t_{\text {hitung }}$ lebih besar dari $t_{\text {tabel }}\left(t_{\text {hitung }}>t_{\text {tabel }}\right)$, sehingga hasil penelitian adalah signifikan. Hal ini berarti, terdapat pengaruh yang signifikan model pembelajaran Cooperative Integrated Reading and Composition (CIRC) berbantuan penilaian portofolio. Terhadap keterampilan membaca pemahaman siswa kelas V di SD Gugus XV Kecamatan Buleleng.

Perbedaan keterampilan membaca pemahaman antara kelompok siswa yang dibelajarkan dengan menggunakan model pembelajaran Cooperative Integrated Reading and Composition (CIRC) berbantuan penilaian portofolio dan kelompok siswa yang dibelajarkan tidak menggunakan model pembelajaran Cooperative Integrated Reading and Composition (CIRC) berbantuan penilaian portofolio disebabkan oleh adanya perlakuan pada kegiatan pembelajaran dan proses penyampaian materi. Dalam model pembelajaran Cooperative Integrated Reading and Composition (CIRC) berbantuan penilaian portofolio memberikan kesempatan kepada siswa untuk menemukan pengetahuannya didalam pembelajaran. Dalam proses pembelajaran CIRC siswa diarahkan untuk membentuk sebuah kelompok secara heterogen yang terdiri dari 5-6 siswa dalam satu kelompok. Dalam kelompok siswa membaca secara paham dan saling berdiskusi mengenai tugas yang diberikan oleh guru secara tertulis dengan beberapa waktu yang ditentukan, setelah berdiskusi siswa dapat membacakan kedepan hasil diskusinya. Hal ini untuk mengetahui tingkat pemahaman siswa terhadap tugas/bacaan yang diberikan oleh guru. Sehingga berdampak bagi siswa mampu saling menghargai masukan teman dalam kelompok dan 
pendapat antar kelompok serta siswa dapat menambah pengalaman setelah membacakan kedepan, mengasah dalam berpikir siswa, memperluas wawasan siswa karena setelah siswa membaca diajarkan untuk dapat menuliskan apa yang telah dipahami dari bacaan tersebut, serta dapat menciptakan suasana pembelajaran yang menarik. Hal ini didukung oleh Suantini (2013) bahwa, model pembelajaran Cooperative Integrated Reading and Composition (CIRC) pada umumnya dapat dipahami sebagai pembelajaran yang terjadi dalam kelompok-kelompok kecil dimana setiap siswa memiliki hak untuk mengungkapkan idenya dan kerjasama untuk menyelesaikan tugas yang diberikan oleh guru.

Dalam pembelajaran CIRC ini dibantu dengan penilaian portofolio. Penerapan penilaian portofolio di dalam proses pembelajaran yaitu setelah penyampaian materi, siswa membuat sebuah portofolio mengenai materi pada pertemuan tersebut secara individu. Untuk melihat hasil dari penilaian portofolio tersebut, guru melihat kesesuaian dari isi portofolio dengan materi ajar dan proses siswa dalam mengikuti pembelajaran disetiap pertemuan yang nantinya guru memberikan sebuah komentar dari hasil portofolio siswa dan bagi siswa yang merasa kurang, dipertemuan selanjutnya akan diberikan bimbingan oleh guru. Hal ini sesuai dengan pendapat Maesuri (dalam Trianto, 2014:295) menyatakan, portofolio berguna bagi guru untuk mengidentifikasi letak kelemahaman dan kelebihan siswa atau memberi nilai yang berarti bagi siswa, sehingga dalam penilaian portofolio mempermudah siswa memahami/mengingat materi yang didapatkan, sebagai bukti fisik yang menunjukkan hasil kinerja siswa serta dapat mendokumentasikan prestasi siswa. Hal ini didukung oleh Jihad (2013:112) bahwa, "portofolio adalah penilaian berkelanjutan yang didasarkan pada kumpulan informasi yang menunjukkan perkembangan kemampuan peserta didik dalam suatu periode". Dibandingkan kelompok kontrol yang dibelajarkan tidak menggunakan model pembelajaran Cooperative Integrated Reading and Composition (CIRC) berbantuan penilaian portofolio yaitu siswa hanya menerima materi apa yang disampaikan oleh guru tanpa adnya interaksi baik antara siswa dengan siswa, serta siswa dengan guru dan juga dilihat dari segi keaktifan siswa dalam mengikuti proses pembelajaran. Dalam proses mengajar dominan guru masih menggunakan motode ceramah, dilihat ketika guru dalam menyampaikan materi secara lisan didepan kelas. Sehingga siswa merasa tidak bersemangat dan kuang antosias dalam mengikuti pembelajaran. Hal ini dukung oleh Sumantri dan Permana (1999:136) bahwa, metode ceramah adalah penyajian pelajaran oleh guru dengan cara memberikan penjelasan secara lisan kepada peserta didik.

Hasil penelitian ini sejalan dengan hasil penelitian yang dilakukan oleh (Wedayanti, 2013) yang berjudul Pengaruh Model Pembelajaran CIRC Berbantuan Gambar Berseri Terhadap Keterammpilan Membaca dan Menulis Siswa Kelas IV SDN 18 Pemecutan. Dalam penelitiannya dapat disimpulkan bahwa terdapat secara signifikan keterampilan membaca dan menulis antara siswa yang dibelajarkan dengan menggunakan model pembelajaran Cooperative Integrated Reading and Composition (CIRC) berbantuan gambar berseri berpengaruh terhadap keterampilan membaca dan menulis siswa kelas IV SDN 18 Pemecutan, Denpasar Utara.

Berdasarkan pemaparan hasil penelitian, dapat diinterprestasi bahwa terdapat berbedaan yang signifikan keterampilan membaca pemahaman antara kelompok siswa yan dibelajarkan dengan menggunakan model pembelajaran Cooperative Integrated Reading and Composition (CIRC) berbantuan penilaian portofolio dan kelompok siswa yang dibelajarkan tidak menggunakan model pembelajaran Cooperative Integrated Reading and Composition (CIRC) berbantuan penilaian portofolio pada siswa kelas V di SD Gugus XV Kecamatan Buleleng Tahun Pelajaran 2017/2018. Dengan demikian, model pembelajaran Cooperative Integrated Reading and Composition (CIRC) berbantuan penilaian portofolio berpengaruh terhadap keterampilan membaca pemahaman siswa.

\section{Simpulan dan Saran}

Berdasarkan hasil penelian dan pembahasan dapat disimpulakan bahwa, keterampilan membaca pemahaman kelompok siswa yang dibelajarkan dengan menggunakan model 
pembelajaran Cooperative Integrated Reading and Composition (CIRC) berbantuan penilaian portofolio pada siswa kelas V di SD Gugus XV Kecamatan Buleleng Tahun Pelajaran 2017/2018 berada pada kategori sangat baik. Jika dikonvensikan dalam grafik poligon, kurva sebaran datanya yaitu juling negatif, yang artinya sebagian besar skor yang diperoleh siswa cenderung tinggi. Keterampilan membaca pemahaman siswa kelompok yang tidak dibelajarkan menggunakan model pembelajaran Cooperative Integrated Reading and Composition (CIRC) berbantuan penilaian portofolio pada siswa kelas V di SD Gugus XV Kecamatan Buleleng Tahun Pelajaran 2017/2018 berada pada kategori cukup, jika dikonvensikan dalam grafik poligon, kurva sebaran datanya yaitu juling positif. Yang artinya sebagian besar skor yang diperoleh siswa cenderung rendah. Sehingga terdapat perbedaan yang signifikan keterampilan membaca pemahaman antara kelompok siswa yang dibelajarkan dengan menggunakan model pembelajaran Cooperative Integrated Reading and Composition (CIRC) berbantuan penilaian portofolio dan kelompok siswa yang dibelajarkan tidak menggunakan model pembelajaran Cooperative Integrated Reading and Composition (CIRC) berbantuan penilaian portofolio pada siswa kelas V di SD Gugus XV Kecamatan Buleleng Tahun Pelajaran 2017/2018.

Berdasarkan dengan hasil penelitian yang diperoleh maka dapat diajukan beberapa saran yaitu sebagai berikut. kepada siswa, hendaknya lebih aktif mencari sumber belajar lain sebagai tambahan sebagai bahan bacaan. Kepada guru, disarankan supaya mencoba melakukan inovasi dalam pembelajaran bahasa Indonesia khususnya keterampilan membaca pemahaman seperti menggunakan model-model pembelajaran yang inovatif dan menggunakan penilaian non tes, salah satu model pembelajaran cocok digunakan yaitu Cooperative Integrated Reading and Composition (CIRC) berbantuan penilaian portofolio sehingga dapat berpengaruh positif terhadap keterampilan membaca pemahaman siswa. Kepada kepala sekolah, disarankan agar selalu memotivasi penerapan model pembelajaran Cooperative Integrated Reading and Composition (CIRC) berbantuan penilaian portofolio agar dapat meningkatkan keterampilan membaca pemahaman siswa. Kepada peneliti lain, hendaknya meneliti permasalahan ini agar lebih mendalam dengan sampel yang lebih luas dan variabel yang lebih bervariasi, sehingga diperoleh hasil penelitian yang lebih baik.

\section{Daftar Rujukan}

Amirono dan Daryanto. 2016. Evaluasi dan Penilaian Pembelajaran Kurikulum 2013. Yogyakarta: GAVA MADIA

Jihad, Asep. 2013. Evaluasi Pembelajaran. Jakarta: Multi Presindo.

Kartika Istri. 2013. Pengaruh Model Pembelajaran CIRC Berbasis Jolly Phonics Terhadap Kemampuan Membaca dan Menulis Siswa Kelas II SD Gugus II Kecamatan Sukawati MIMBAR PGSD Undiksha Vol1, No 1 (2013).

Kurniasih dan Sani. 2015. Ragam pengembangan model pembelajaran. Jakarta: Kata Pena

Nasution, S . 2004. Sosiologi Pendidikan. Jakarta: PT Bumi Aksara.

Prabawati Chandra. 2013. Pengaruh Model Circ Berbantuan Media Gambar Berseri Terhadap Kemampuan Membaca Pemahaman pada Siswa Kelas V SD Gugus IV Kecamatan Rendang. MIMBAR PGSD Undiksha Vol1, No 1 (2013).

Shoimin, Aris. 2014. Model pembelajaran inovatif dalam kurikulum 2013. Yogyakarta: ARRUZZ MEDIA. 
Suantini, Ni L. P. Yuni. 2013. "Pengaruh Model Pembelajaran Kooperatif Tipe CIRC Terhadap Pemahaman Konsep IPA Siswa Kelas IV di Gugus II Kecamatan Gerokgak". Jurnal. Jurusan PGSD Undiksha

Sudiana, I Nyoman. 2007. Membaca. Malang: Universitas Negeri Malang (UM PRESS)

Sumantri, Mulyani dan Johar Permana. 1999. Strategi Belajar Mengajar. Singaraja: Undiksha

Tarigan, Henry Guntur. 1985. Membaca Sebagai Suatu Keterampilan Berbahasa. Bandung: ANGKASA

Wedayanti, Ni Wyn. Anggun. 2013. "pengaruh model pembelajaran CIRC berbantuan gambar berseri terhadap keterampilan membaca dan menulis siswa kelas IV SDN 18 pemecutan". Journal. Jirisan PGSD Undiksha. 